\title{
Peningkatan Hasil Belajar Keragaman Budaya Melalui Model Problem Based Learning di SDN Prawit 1 Surakarta
}

\author{
Azizah Rahmawati \\ Universitas Sebelas Maret \\ rahmajazz@gmail.com
}

\section{Article History}

received 30/4/2021

\begin{abstract}
Improving the results of learning cultural diversity through the application of problem based learning model. The purpose of this study is to improve the learning outcomes of cultural diversity in grade IV students of SDN Prawit 1 Surakarta through the implementation of problem based learning model. Class Actions were performed in two cycles. The research subjects were students of class IV SDN Prawit 1 Surakarta in 2020/2021 totaling 30 children. Data collection techniques used were observation, tests, and documentation. The data analysis technique used was a comparative descriptive analysis model and interactive analysis through three stages, namely, data reduction, data presentation, and drawing conclusions. The initial condition before the action, the percentage of classical class completeness was $33.33 \%$. The percentage of classical completeness after being given an action in the first cycle became $56.67 \%$, the percentage of classical completeness in the second cycle became $83.33 \%$. Based on these results, it can be concluded that the application of the Problem Based Learning model can improve the learning outcomes of the fourth grade students of SDN Prawit 1 Academic Year 2020/2021.
\end{abstract}

Keywords: Problem Based Learning, Cultural Diversity learning outcomes

\section{Abstrak}

Peningkatan hasil belajar keragaman budaya melalui penerapan model Problem Based Learning. Tujuan dari penelitian ini untuk meningkatkan hasil belajar keragaman budaya pada peserta didik kelas IV SDN Prawit 1 Surakarta melalui penerapan model Problem Based Learning. Tindakan Kelas dilakukan dalam dua siklus. Subjek penelitian adalah peserta didik kelas IV SDN Prawit 1 Surakarta tahun 2020/2021 berjumlah 30 anak. Teknik pengumpulan data yang digunakan adalah observasi, tes, dan dokumentasi. Teknik analisis data yang digunakan yaitu model analisis deskriptif komparatif dan analisis interaktif melalui tiga tahap yaitu, reduksi data, penyajian data, dan penarikan kesimpulan. Kondisi awal sebelum tindakan, persentase ketuntasan klasikal kelas adalah $33,33 \%$. Persentase ketuntasan klasikal setelah diberi tindakan siklus I menjadi $56,67 \%$, persentase ketuntasan klasikal tindakan pada siklus II menjadi $83,33 \%$. Berdasarkan hasil tersebut, dapat disimpulkan bahwa penerapan model Problem Based Learning dapat meningkatkan hasil belajar keragaman budaya peserta didik kelas IV SDN Prawit 1 Tahun Ajaran 2020/2021.

Kata kunci: Problem Based Learning, hasil belajar Keragaman Budaya 


\section{PENDAHULUAN}

Penerapan kurikulum 2013 berbasis pembelajaran tematik saat ini diharapkan dapat membentuk karakter serta mengembangkan keterampilan peserta didik. Pembelajaran tematik merupakan keterpaduan antar mata pelajaran yang saling terkait dalam suatu tema tertentu sehingga dapat memberikan pengalaman bermakna kepada peserta didik. Proses pembelajaran tematik yang berpusat pada peserta didik (student centered active learning), menuntut guru untuk cermat dalam mendesain setiap pembelajaran yang bermakna bagi peserta didik. Penggunaan model pembelajaran dan perangkat media pembelajaran yang menarik menjadi salah satu kunci dalam keberhasilan pembelajaran tematik. Selain student centered, ketrampilan abad 21 juga menekankan peserta didik memiliki keterampilan berpikir kritis akan pengetahuan baru, memiliki kemampuan literasi digital, literasi informasi, literasi media serta menguasai teknologi informasi dan komunikasi. Frydenberg \& Andone (2011: 314). Hal ini diperkuat Baysal (2017) bahwa Model Problem Based learning sangat berpengaruh pada pembelajaran baik dalam hal kolaborasi maupun proses pemerolehan ketrampilan.

Berdasarkan data yang diperoleh dari daftar nilai analisis, perbaikan, pengayaan, pengolahan dan pelaporan hasil belajar kelas IV SDN Prawit 1 tahun ajaran 2019/2020 menunjukkan banyaknya peserta didik yang memiliki hasil belajar rendah, khususnya pada nilai hasil ulangan materi keragaman budaya. Cakupan materi keberagaman budaya yang sangat luas membuat peserta didik mengalami kesulitan dalam memahami konsep keragaman budaya secara utuh. Selain itu peserta didik kurang terlibat aktif dalam pembelajaran. Untuk mengatasi permasalahan pembelajaran tersebut dapat menerapkan model pembelajaran yang dapat diterapkan yaitu model Problem Based Learning (Pembelajaran Berbasis Masalah). Model Problem Based Learning merupakan suatu model pembelajaran yang fokus utamanya adalah penyajian masalah-masalah dan mencari cara penyelesaiannya.

Rumusan masalah dalam penelitian tindakan kelas ini, yaitu Apakah penerapan model Problem Based Learning dapat meningkatkan hasil belajar tentang keragaman budaya tema 7 indahanya keragaman di negeriku pada peserta didik kelas IV SDN Prawit 1 Surakarta tahun ajaran 2020/2021

Tujuan penelitian ini adalah untuk meningkatkan hasil belajar tentang keragaman budaya tema indahnya keragaman di negeriku melalui penerapan model Problem Based Learning pada peserta didik kelas IV SDN tahun ajaran 2020/2021.

\section{METODE}

Penelitian Tindakan Kelas ini dilaksanakan di SDN Prawit 1 Surakarta dari bulan Januari hingga Mei 2021. Subjek penelitian ini adalah peserta didik kelas IV tahun ajaran 2020/2021 yang berjumlah 30 peserta didik yang terdiri dari 15 peserta didik laki-laki dan 15 peserta didik perempuan.

Data yang digunakan dalam penelitian ini diperoleh dari observasi, tes, dan dokumentasi. Teknik analisis data yang digunakan yaitu model analisis deskriptif komparatif dan analisis interaktif melalui tiga tahap yaitu, reduksi data, penyajian data, dan penarikan kesimpulan sesuai model analisis yang dikemukakan Miles dan Huberman (dalam Sugiyono: 2017).

Keberhasilan penelitian tindakan kelas ini dapat dilihat dari beberapa indikator, sebagai berikut: Seorang peserta didik dikatakan tuntas belajar apabila telah mencapai nilai sesuai dengan KKM yang telah ditentukan sebesar $\geq 70$, sedangkan ketuntasan belajar klasikal tercapai apabila $\geq 75 \%$ peserta didik di kelas tersebut telah mencapai ketuntasan belajar. Sudjana (2011:124). 


\section{HASIL DAN PEMBAHASAN}

Penerapan model Problem Based Learning untuk meningkatkan hasil belajar keragaman budaya di Tema 7 pada peserta didik kelas IV SDN Prawit 1 dilakukan dalam dua siklus dan pada tiap siklusnya terdiri dari 2 pertemuan melalui zoomeeting dan Whatsapp interaktif.

Proses pembelajaran yang dilaksanakan yaitu sebagai berikut: (1) Orientasi masalah pada kegiatan awal penyampaian materi untuk merangsang kemampuan berfikir kritis peserta didik (2) mengorganisasi siswa untuk belajar dengan membuat kelompok diskusi kecil dalam kegiatan kolaborasi (3) membimbing penyelidikan dengan mengerjakan LKPD (4) mengembangkan hasil karya dari temuan (5)menyajikan hasil karya dalam webmeeting dengan menunjukkan kreativitas (6) menganalisis dan mengevaluasi proses pemecahan masalah sebagai refleksi pembelajaran. Langkah-langkah tersebut merupakan penerapan dari langkah Problem Based Learning yang dikemukakan oleh Forogarty (dalam Rusman, 2014: 243).

Hasil penerapan model Problem Based learning menunjukkan peningkatan hasil belajar keragaman budaya pada setiap siklusnya hingga mencapai indikator ketuntasan yang telah ditargetkan yaitu sebesar $80 \%$.

Tabel 1. Perbandingan Data Penerapan Model Problem Based Learning untuk meningkatkan hasil belajar keragaman budaya antar siklus

\begin{tabular}{lccc}
\hline \multicolumn{1}{c}{ Pencapaian } & Prasiklus & Siklus I & Siklus II \\
\hline Nilai Tertinggi & 80 & 90 & 94 \\
Nilai Terendah & 20 & 55 & 57 \\
Rata-rata & 57,4 & 71,5 & 75,7 \\
Ketuntasan & $33,33 \%$ & $56,67 \%$ & $83,33 \%$ \\
\hline
\end{tabular}

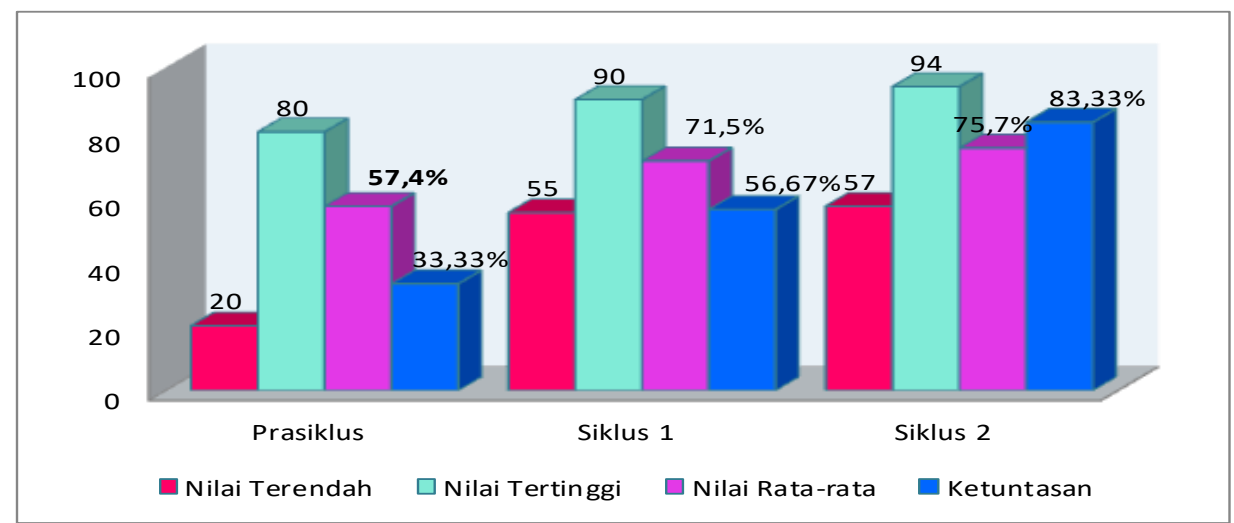

Gambar 1. Grafik Perbandingan Nilai Antarsiklus Hasil belajar Keragaman Budaya Peserta Didik Kelas IV SDN Prawit 1 Surakarta

Berdasarkan Tabel 1, dapat disimpulkan bahwa dari penelitian yang dilaksanakan terjadi peningkatan hasil belajar keragaman budaya melalui penerapan model Problem Based Learning. Sebelum diterapkan model Problem Based Learning, presentasi ketuntasan prasiklus sebesar $33,33 \%$. Kemudian setelah diterapkan model Problem based Learning maka hasilnya meningkat menjadi 56,67\%. Hasil tersebut belum mencapai indikator kinerja yang telah ditargetkan yaitu sebesar $80 \%$. Setelah dilakukan refleksi, kemudian mengadakan perlakuan pada siklus II maka hasilnya meningkat menjadi 83,33\%. Dengan demikian penelitian diakhiri pada siklus II karena telah tercapai indikator kinerja yang diharapkan. 
Data yang diperoleh dan disajikan dalam tabel hasil penelitian tersebut membuktikan bahwa penerapan model Problem Based Learning dapat meningkatkan hasil belajar peserta didik. Temuan ini sejalan dengan penelitian Abdul, Haris (2013) yang menyatakan bahwa penerapan model Problem Based Learning berpengaruh signifikan terhadap kemampuan memecahkan masalah IPS. Hal ini diperkuat oleh Imas \& Sani (2015: 49) yang menjelaskan bahwa pelaksanaan pembelajaran dengan model Problem Based Learning memiliki keunggulan diantaranya peserta didik mampu mengembangkan berfikir kritis, kreatif dan berlatih memecahkan permasalahan. Oleh karenanya maka akan menjadikan suatu proses belajar yang bermakna serta menumbuhkan inisiatif dan motivasi dalam belajar. Melalui model Problem Based Learning, peserta didik dapat mengembangkan hubungan interpersonal dalam bekerja kelompok. Maka hal ini akan sejalan dengan pengembangan kemampuan 4C (Critical thinking, creativity, communication skills dan collaborative) peserta didik sesuai tuntutan abad 21. Selain itu, penelitian lain menyebutkan bahwa model Problem Based Learning mampu meningkatkan kemampuan pemecahan masalah pada mata pelajaran IPS dengan hasil penelitian membuktikan sebelum dilakukan tindakan ratarata nilai hasil belajar peserta didik 57,4 (cukup), pada siklus I pertemuan I 63,3 (baik), pertemuan II 69,0 (baik). Hasil tersebut mengalami kenaikan signifikan pada siklus II pertemuan I yaitu 78,6 (baik) dan pada pertemuan II telah mencapai 83,6 (baik sekali).

Hasil penelitian ini dalam pelaksanaannya juga mengalami beberapa kendala teknis seperti (1) kurang optimalnya pembelajaran karena dilakukan secara daring karena terdapat peserta didik yang tidak dapat masuk pada web meeting, (2) kurangnya efektifnya pengerjaan evaluasi karena dikerjakan dari rumah masingmasing peserta didik (3) waktu pengumpulan tugas belum sesuai waktu yang telah ditentukan. Kendala tersebut dapat diatasi dengan komunikasi melalui whatsapp baik secara personal maupun melalui whatsapp grup untuk melaksanakan kegiatan pembelajaran sebaik-baiknya.

Berdasarkan hasil penelitian yang telah diuraikan, maka dapat disimpulkan bahwa penerapan model Problem Based Learning mampu meningkatkan hasil belajar keragaman budaya peserta didik kelas IV SDN Prawit 1 Surakarta.

\section{SIMPULAN}

Berdasarkan hasil penelitian yang telah dilaksanakan selama dua siklus dapat ditarik simpulan bahwa pembelajaran dengan penerapan model Problem Based Learning dapat meningkatkan hasil belajar keragaman budaya peserta didik kelas IV SDN Prawit 1 Surakarta. Peningkatan tersebut dapat dibuktikan dengan meningkatnya nilai rata-rata hasil belajar keragaman budaya pada setiap siklusnya, yaitu pada prasiklus nilai rata-rata hasil belajarkeragaman budaya peserta didik hanya 57,4 , siklus I nilai rata-rata hasil belajar meningkat menjadi 71,5 , dan pada akhir siklus II nilai ratarata hasil belajar menjadi 75,7. Tingkat ketuntasan belajar peserta didik pada prasiklus sebesar 33,33\% atau 10 anak. Pada siklus I tingkat ketuntasan sebesar 56,67\% atau 17 anak. Sedangkan pada siklus II tingkat ketuntasan sebesar $83,33 \%$ atau 25 anak. Hal ini menunjukkan peningkatan dari prasiklus ke siklus I sebesar 23,34\%, peningkatan dari siklus I ke siklus II sebesar $26,66 \%$, dan peningkatan ketuntasan dari prasiklus sampai siklus II sebesar 50\%. Dengan demikian secara klasikal pembelajaran telah mencapai ketuntasan belajar yang ditargetkan.

Berdasarkan hasil penelitian yang telah dikemukakan di atas, maka ada beberapa saran untuk pendidik guna meningkatkan pembelajaran diantaranya: (1) guru hendaknya merencanakan secara matang proses pembelajaran yang akan dilaksanakan dengan menentukan metode, media, serta sarana pembelajaran yang dapat digunakan sesuai tujuan pembelajaran yang akan dicapai serta kondisi ada terlebih di masa pandemi, (2) melakukan bimbingan baik secara personal maupun 
kelompok untuk peserta didik yang mengalami hambatan, (3) melakukan refleksi diri guna mencapai targer yang diharapkan.

\section{DAFTAR PUSTAKA}

Abdul, Haris (2013). Pengaruh Penerapan Model Problem Based Learning Terhadap Kemampuan Memecahkan Masalah Dalam Pembelajaran IImu Pengetahuan Sosial Pada Siswa Kelas Iv Sekolah Dasar Negeri Blondo 1 Magelang. Diakses 20 Desember 2020 dari https://eprints.uny.ac.id/15968/

Baysal, Zeliha Nurdan. (2017). The Problem-Based Learning Process: Reflections Of Pre-Service Elementary School Teachers. Academic Journal. Vol 12 (4) pp.177188. Diakses 17 Januari 2020.

Frydenberg, M. E., Andone, D. (2011). Learning for 21st Century Skills. IEEE's International Conference on Information Society, London, 27-29 June 2011, 314318. Diakses pada 12 Desember 2020.

Imas Kurniasih \& Berlin Sani. (2015). Ragam Pengembangan Model Pembelajaran untuk Peningkatan Profesionalitas Guru. Jogjakarta: Kata Pena.

Nafisah. (2010). Penerapan Pembelajaran Model Problem Based Learning untuk Meningkatkan Kemampuan Pemecahan Masalah Mata Pelajaran IPS Siswa Kelas IV SDN Lebak Winongan Pasuruan. Skripsi. Jurusan Kependidikan Sekolah Dasar \& Prasekolah - Fakultas IImu Pendidikan UM. Diakses 10 Desember 2020.

Rusman. (2014). Metode-Metode Pembelajaran: Mengembangkan Profesionalisme Guru. Jakarta: PT RajaGrafindo Persada.

Sugiyono. (2017). Metode Penelitian Pendidikan Pendekatan Kuantitatif, Kualitatif, dan R\&D. Bandung: Alfabeta. 